\title{
Working Capital Management and Return on Assets of Manufacturing Industry of Perú
}

\author{
Wagner Enoc Vicente-Ramos ${ }^{1}$, Marianela Roxana Ames Porras ${ }^{1}$, Roberson Meza Quispe ${ }^{1}$ \& Miguel Angel Rojas \\ Zacarias $^{1}$ \\ ${ }^{1}$ Universidad Continental, Peru \\ Correspondence: Wagner Enoc Vicente-Ramos, Coordinador de Investigación de la Facultad de Ciencias de la \\ Empresa de la Universidad Continental, Peru.
}

Received: December 31, 2019

Accepted: January 31, 2020

Online Published: March 22, 2020

doi:10.5430/ijfr.v11n2p382

URL: https://doi.org/10.5430/ijfr.v11n2p382

\begin{abstract}
This article contributes to the increase in knowledge and existing theory about the administration of working capital and its relation to profitability. Using a sample of 23 companies listed on the Lima stock exchange during the period 2009-2018. There is a negative relationship between profitability (ROA) and the average inventory period (PPI), in the same way a negative relationship between profitability and the average collection period (PPC), finally a positive relationship between profitability and the period average payment (PPP). It is concluded that a company of the industrial sector in Peru, manages to be more efficient, effective and competitive insofar as it improves the management of working capital, which is achieved if it achieves effective management of financial resources, an equitable policy of Customer credit, proper inventory management and proper management of supplier leverage and short term.
\end{abstract}

Keywords: management of working capital, profitability, return on assets, cash conversion cycle

\section{Introduction}

The manufacturing industry is one of the sectors that has a very significant presence and contribution in the economy of a country. In Peru, it constitutes the sector with the highest participation in PBI with $13 \%$, in taxes with $18 \%$ and generation of direct jobs of more than 1.5 million workers in 2018, according to a report by the Institute of Economic and Social Studies (IEES) of the National Society of Industries (SNI). In addition, industry is always an important source of economic and social progress (SNI, 2016, P. 3). However, in our country the industrial production, presents a not very pleasant antecedent since during four consecutive years (2014-2017) it experienced a significant recession, with a fall of $7.3 \%$, causing the loss of more than 75 thousand jobs; the worst result in 70 years (SNI, 2018); In addition, in the presentation of the Economy and Development Report - RED 2018, the representative of the Development Bank of Latin America (CAF), Malaret, M. (2018), said that the economic lag in the countries of the region, among them Peru; compared to advanced economies in Europe, Asia and North America, it is mainly due to the low level of productivity, and this in turn is caused by lower innovation and inefficient administration and distribution of capital in companies.

The administration of working capital is the efficient management of all current accounts including current assets and liabilities of a company; It is an important element in decision-making since this is reflected in sales, and therefore, the good results obtained will allow you to have a good liquidity and profitability (Núñez, 2016). In that sense, there is an urgent need to optimize the management of working capital, requiring companies to concentrate on the more rational use of their resources and the control of their processes, that is, on having a comprehensive administration of their short-term assets and liabilities, since the viability of its operations and validity in the market, depends on efficiently managing the inventory, cash, accounts payable and accounts receivable; so that a balance between risk and profitability can be obtained that helps to increase the value of the company (Gitman and Zutter, 2016). This article contributes to the increase in knowledge and existing theory on the administration of working capital and its relation to profitability. The results contribute to the decision-making of company executives regarding the monetary needs of the company to ensure the normal development of their activities. 


\section{Literary Review}

The administration of working capital becomes the management of short-term assets and liabilities of companies; that is, each item such as cash, inventory, accounts receivable and accounts payable, are necessary to contribute to the performance and proper management of the company. (Van Horne \& Wachowicz, 2010). According to Espinoza (2005), the administration of working capital is the process of operational financial management, which is dedicated to the planning, execution and control of the management of the components of working capital and their adequate levels and quality, which allow minimizing risk and maximize business profitability.

The main objective that the administration of working capital seeks is to have a domain over all accounts of current assets, as well as their financing, and to achieve a balance between risk and profitability (Van Horne \& Wachowicz, 2010). Therefore, efficient management of working capital is vital, especially for manufacturing companies, in which most of their assets are made up of current assets (Deloof, 2003).

The efficient management of working capital involves the planning and control of current assets and liabilities in a way that eliminates risks and ensures compliance with short-term obligations and, on the other hand, avoids excessive investment in assets (Eljelly, 2004). Gitman \& Chad (2012), considers that profitability is the positive residue between earned and spent, for which it is necessary to increase sales and minimize costs through the correct selection of inputs, labor and any indirect costs. Profitability can also be defined as the benefit generated by an investment, expressed as a percentage. However, the monetary value perceived as a consequence of it varies depending on the investment placement time.

\subsection{Background}

Aqil, Raheem, Vveinhardt and Streimikiene (2019) in their scientific article "Factors Influencing the Profitability of Heavy Vehicle Industry: A Case of Pakistan" in which five companies from Pakistan's heavy vehicle industry were studied in the period of 2005 to 2017; they obtained that the relationship between cash and marketable securities has a significant impact on asset performance. In other words, greater asset availability positively affects the profitability of Pakistan's heavy vehicle industry. Likewise, they determined that the factors influencing the performance of Pakistan's heavy vehicle industry assets are the rapid relationship, inventory turnover, accounts receivable turnover and average accounts payable; However, the influence of the cash conversion cycle and the size of the business were not significant.

Dalci, Tanova, Ozyapici and Bein (2019) in their scientific article "The Moderating Impact of Firms size on the Relationship Between Working Capital Management and Profitability", in which they studied 285 companies over a period of 8 years. The results of the investigation reveal that the relationship between the cash conversion cycle and profitability is moderated by the size of the company; consequently as the size of the company decreases and the cash conversion cycle lengthens, the profitability of the assets decreases; and when the size of the company increases and the cash conversion cycle lengthens, the return on assets increases.

Nobanee (2018) in his article "Efficiency of Working Capital Management and Profitability of UAE Construction Companies: Size And Crisis Effects", in which he studied 112 companies during the years 2003-2013, resulted in a significant negative relationship between the net business cycle as an integral measure of efficiency in working capital management and profitability for the full sample. Likewise, the relationship between the net business cycle and profitability for small ente rprises is positive and insignificant, indicating that small construction companies in the UAE (United Arab Emirates) do not manage their working capital efficiently. However, large companies are more efficient in managing their working capital. The results also show a positive and significant relationship between the net business cycle and the profitability of construction companies in the UAE during periods of non-crisis and a negative and significant relationship during the crisis periods; this indicates that construction companies in the UAE are more efficient in managing their working capital during the crisis period.

Linh and Mohanlingam (2018) in his research entitled "The effects of cash conversion cycle on profitability: an insight into the agriculture and food industries in Thailand" in which 34 companies were studied in the period 2009 2013, the results indicate that the cash conversion cycle (CCC) has a significant inverse relationship with profitability in agricultural and food enterprises in Thailand. Furthermore, it found that the production cycle and the debt index had a significant negative relationship with the return on assets (ROA), while the payment cycle and size had a positive relationship with the return on equity (ROE). No significant relationship was found between the collection cycle and profitability. 


\subsection{Management of Working Capital}

The administration of working capital includes all aspects of planning and control of the resources of a company, whose primary objective is to manage each of the current assets and liabilities of the company; Current assets must grow to the point where performance and assets are equal to the cost of capital required to finance such increases. Current liabilities must be used instead of long-term debts; in such a way that a balance between profitability and risk levels is achieved to maximize the value of the company (Azapa, 2017). For Castañeda (2016), the importance of working capital is unquestionable since the operations of a company depend on the ability to efficiently manage current assets, accounts receivable and accounts payable, and thus achieve a balance between profitability and risk that helped maximize the value of the company and keep it operational in the market.

\subsection{Profitability}

Rodríguez (2017) considers that profitability is the company's ability to generate profits or increase its net assets. It serves third parties or beneficiaries in general to measure the net profit or changes of the company's net assets in relation to its income, working capital and its assets. Profitability can also be defined as the benefit generated by an investment, expressed as a percentage. However, the monetary value perceived as a result of it varies depending on the investment placement time.

The average inventory period (PPI) or also called stock rotation, according to Albisetti (2018) is represented as a relationship between sales and warehouse stocks. This relationship indicates the speed of inventory turnover, that is, the number of times in a year that the inventory is reintegrated or understood as well as the days of inventory stock keeping. The faster the stock sales occur, the greater the profitability and the opposite will happen the slower the sales.

The average collection period (PPC) or also called rotation of accounts receivable, is defined as the time the company must wait to collect its credits; Therefore, a longer average collection period causes a greater demand for working capital, which may mean a need to take loans with the banking system (Albisetti, 2018).

With respect to the average payment period (PPP) or the average period of accounts payable, this is the period of time that the company makes its suppliers wait before paying their debts. An increase in the average payment period may mean that you are using debt with suppliers to finance acquisitions of fixed assets (Albisetti, 2018).

Cabrera (s.f.) considers that as a general rule, it is always desirable that the average payment period be greater than the average collection period, since a part of a company's financing comes from its suppliers; nevertheless it is necessary to avoid affecting them, building a win-win relationship for everyone.

\section{Method}

\subsection{Population and Sample}

The research has a quantitative approach because it is based on numerical measurement and statistical analysis; and it is of the applied type because it is based on the existing theory. The level of research is correlational for the purpose of determining the relationship between the administration of working capital and the profitability of companies in the Peruvian manufacturing industry during the period 2009-2018.

Considered as a population to the industrial sector, made up of 42 manufacturing companies in Peru that are listed on the Lima Stock Exchange. The sample is of 24 manufacturing companies that meet the following inclusion and exclusion criteria: manufacturing companies, financial statements published in the Superintendence of the Stock Market, financial statements with complete information in the period 2009-2018; and with inventories, accounts receivable and accounts payable greater than zero in at least five periods. The type of sampling used was non-probabilistic sampling by criteria.

According to Fernández (2004), the criterion sampling method is based on the investigator's criteria to select representative sample units. The experience and knowledge of the researcher about the subject and the population involved will serve as a basis to determine the criteria for carrying out a sample selection.

Table 1. Companies in the manufacturing industry sector of Peru

\begin{tabular}{ll}
\hline Business & Location \\
\hline Compañía Universal Textil S.A. & Lima, Lima \\
\hline Corporación Aceros Arequipa. S.A. & Pisco, Ica \\
\hline
\end{tabular}




\begin{tabular}{ll}
\hline Creditex S.A. & Ate Vitarte, Lima \\
\hline Exsa S.A. & Lurín, LIma \\
\hline Indeco S.A. & Lima, Lima \\
\hline Unión Andina de Cementos S.A. & Villa María del Triunfo, Lima \\
\hline Manufactura de Metales y Aluminio Record S.A & Ate Lima \\
\hline Lima Caucho S.A. & Santa Anita, Lima \\
\hline Agroindustria AIB S.A. & Miraflores, Lima \\
\hline Austral Group S.A. & Callao Lima \\
\hline Consorcio Industrial de Arequipa S.A. & Arequipa, Arequipa \\
\hline Fabrica Nacional de Acumulados ETNA S.A. & Independencia, Lima \\
\hline Hidrostal S.A. & San Juan de Lurigancho, Lima \\
\hline Industrias Electroquímicas IEQSA S.A. & El Callao, Lima \\
\hline Metalúrgica Peruana MEPSA S.A. & Lima, Lima \\
\hline Michell y CIA S.A. & San Lázaro, Arequipa \\
\hline Motores Diesel Andinos S.A. & Ate, Lima \\
\hline Quimpac S.A. & Callao, Lima \\
\hline Cemento Pacasmayo S.A. & Santiago de Surco, Lima \\
\hline Compañ́a Goodyear del Perú S.A. & Callao \\
\hline Corporación Lindley S.A. & Rimac \\
\hline Corporación Cerámica S. A. & San Martín de Porres \\
\hline Yura S.A. & La Victoria, Arequipa \\
\hline Fabrica Peruana Eternit S.A. & Lima \\
\hline
\end{tabular}

\subsection{Data Collection Instrument}

The document review form was used for the annual Individual Financial Statements for the collection of data, specifically the Statement of Financial Position and the Income Statement that are published in the Superintendence of the Stock Market. Numerical data were classified by company and by time, and financial reasons such as the Average Inventory Period (PPI), Average Collection Period (PPC), Average Payment Period (PPP) and Asset Profitability (ROA) were used.

\subsubsection{Study Variables}

The variables that gave rise to this research are Profitability as a dependent variable, considering the Asset Profitability (ROA); and Administration of working capital as an independent variable, considering the Average Inventory Period (PPI), Average Collection Period (PPC) and Average Payment Period (PPP). For the definition of the study variables, Gitman and Zutter (2016), Van Horne and Wachowicz (2010) and Brealey et al. (2015).

In Table 1, the dependent, independent and control variable is presented; each with its respective formula used. The calculations made are supported by the Tanaka theory (2001) for the dependent variable, and Gitman and Zutter (2016), Van Horne and Wachowicz (2010) and Brealey et al. (2015) for the independent variable. As control variables, the total assets (L_TA) where natural logarithm was applied, and sales growth (CV) were considered; based on the research carried out by Jaramillo (2016), Sarwat et al. (2017) and Lindelwa and Zimasa (2019).

\subsubsection{Econometric Model}

Many investigations use the panel data methodology for similar studies, with the aim of processing the data through a number of individuals and time. As background we have the studies of Sarwat et al. (2017), Linh and Mohanlingam (2018) and Lindelwa and Zimasa (2019).

The econometric model of panel data is based on two main estimation techniques, that is, fixed effects and random 
effects, of which in order to determine the most appropriate estimation technique for the investigation, the Hausman test is performed.

The model used to study the administration of working capital and its relationship with the profitability of manufacturing companies in Peru is based on the following studies: Cisne et al. (2018) and Lindelwa and Zimasa (2019). In that sense, the application of the econometric model for this research is supported, which is represented by the following formula:

$$
R O A_{i t}=\beta_{0}+\beta_{1} P P I_{i t}+\beta_{2} P P C_{i t}+\beta_{3} P P P_{i t}+\beta_{4} L_{-} T A_{i t}+\beta_{5} C V_{i t}+\varepsilon_{i t}
$$

Donde:

PPI: inventory turnover period

PPC: average collection period

PPP: average payment period

L_TA: natural logarithm of total assets

CV: sales growth

$\beta_{0}$ : beta coefficient

$\varepsilon_{i t}$ : error term

i: cross section

t: time series dimension

\subsubsection{Hypotheses}

H1: There is a direct relationship between the average inventory period and the profitability of manufacturing companies in Peru 2009 - 2018.

$\mathrm{H} 2$ : There is a direct relationship between the average period of accounts receivable and the profitability of manufacturing companies in Peru 2009 - 2018.

H3: There is a direct relationship between the average period of accounts payable and the profitability of manufacturing companies in Peru 2009 - 2018.

\section{Results}

\subsection{Descriptive Result}

Table 2 shows the descriptive statistics of the variables and the estimate of normality, in which the observations, mean, standard deviation, minimum and maximum of the study variables of manufacturing companies in Peru are detailed, period 2009 - 2018.

Table 2. Summary of descriptive statistics

\begin{tabular}{llllll}
\hline Variable & Observations & Mean & $\begin{array}{l}\text { Standard } \\
\text { Deviation }\end{array}$ & Min. & Max. \\
\hline ROA & 230 & 0.0533 & 0.0425 & -0.0048 & 0.2387 \\
\hline PPI & 230 & 147.78 & 69.72 & 25.274 & 441.64 \\
\hline PPC & 230 & 50.37 & 32.90 & 1.59 & 161.39 \\
\hline PPP & 230 & 53.71 & 31.38 & 5.20 & 187.38 \\
\hline TA & 230 & $1,08 \mathrm{E}+10$ & $1,59 \mathrm{E}+10$ & 38707 & $8,64 \mathrm{E}+10$ \\
\hline CV & 230 & $1,13 \mathrm{E}+09$ & $2,99 \mathrm{E}+09$ & -4901 & $2,62 \mathrm{E}+10$ \\
\hline
\end{tabular}

\subsection{Correlation Coefficient Test}

It is important to perform the correlation coefficient test, for the reason it is used to measure the strength of association between two variables. For this study, it is carried out to determine the relationship between the 
administration of working capital and the profitability of manufacturing companies in Peru.

Table 3 shows that none of the variables correlated with the 5\% significance level, in addition it is worth mentioning that missing values were ignored.

Table 3. Correlation results

\begin{tabular}{lllllll}
\hline Variable & ROA & PPI & PPC & PPP & TA & CV \\
\hline ROA & 1 & & & & & \\
\hline PPI & -0.1694 & 1 & & & & \\
\hline PPC & -0.3493 & 0.3587 & 1 & & & \\
\hline PPP & -0.1718 & -0.1239 & 0.1339 & 1 & & \\
\hline TA & -00888 & 0.0476 & -0.4732 & 0.0008 & 1 & 1 \\
\hline CV & -0.0050 & -0.2309 & -0.2639 & -0.1626 & 0.3422 & 1 \\
\hline
\end{tabular}

It is observed that the variables have a certain degree of correlation with respect to ROA. A positive correlation coefficient means that when one variable increases the other variable increases, and a negative correlation coefficient indicates that as the variable increases the other decreases.

The results indicate that there is a very low negative correlation, between the average inventory period (PPI) with a -0.1694 , average collection period (PPC) with a -0.3493 and the average PPP payment period) with a -0.1718 . Regarding total assets (TA), there is a negative correlation with -00888, and sales growth (CV) with -00888, compared to ROA.

\subsection{Multiple Regression Model for ROA}

To decide on the optimal model, the Hausman Test was performed to determine if the econometric model with fixed or random effects is taken.

In Table 4, the Hausman test is presented in order to decide which model to use for the analysis of the panel data. The Hausman Test has been applied by Cisne et al. (2018), Lindelwa and Zimasa (2019) and Jaramillo (2016) to determine which model to use in the relationship between profitability and the administration of working capital.

Table 4. Regression results

\begin{tabular}{lllll}
\hline & Fixed effects & & Random effects & \\
\hline & Coef. & P value & Coef. & P value \\
\hline Variable & 0.682697 & $2.07 \mathrm{e}-015 * * *$ & 0.422238 & $5.06 \mathrm{e}-015 * * *$ \\
\hline PPI & -0.000133012 & $0.0100 * *$ & $-6.00049 \mathrm{e}-05$ & 0.2063 \\
\hline PPC & -0.000693844 & $8.46 \mathrm{e}-07 * * *$ & -0.000801773 & $5.64 \mathrm{e}-011 * * *$ \\
\hline PPP & 0.000249050 & $0.0158 * *$ & 0.000129242 & 0.1791 \\
\hline L_TA & -0.0448874 & $4.23 \mathrm{e}-012 * * *$ & -0.0249111 & $9.42 \mathrm{e}-010 * * *$ \\
\hline CV & $-1.31709 \mathrm{e}-09$ & 0.8583 & $-2.65690 \mathrm{e}-09$ & 0.7257 \\
\hline $\mathrm{N}$ & 230 & 230 & 230 & 230 \\
\hline R2 & 0.631688 & & &
\end{tabular}

Note: $(*)(* *)$ and $(* * *)$ represent statistical significance at levels of $10 \%, 5 \%$ and $1 \%$, respectively.

In Hausman's contrast after testing the null hypothesis: p-value $=0$ is obtained that is less than 0.005 , so the null hypothesis is rejected and it is concluded that the fixed effects model would be the best option. In addition, R2 shows that $63 \%$ of the variation in ROA was driven by regressors.

\section{Discussion}

\subsection{Inverse Relationship Between the Average Inventory Period and Profitability}

The results indicate that there is a negative correlation between the average inventory period (PPI) and the 
profitability of assets (ROA), with a $-0,000133012$, which is evidenced in Table 4.

It means that the shorter the average days or period of inventories, the greater the return on assets, for the reason that the company's products are sold faster or in the shortest time

The average for PPI was 147.78 days. This means that companies on average required 147 days to sell their inventory or it took them to convert their inventories into sales. The standard deviation was 69.72 days, while it had a minimum of 25.27 days and a maximum of 441.64 days. For the sector, it is considered acceptable for the reason that companies in the industrial sector invest less working capital when inventory days are shorter, contributing to greater profitability of assets.

\subsection{Inverse Relationship Between the Average Period of Accounts Receivable and Profitability}

The results indicate that there is a negative correlation between the average collection period (PPC) and the profitability of assets (ROA), with a -0.000693844 , which is evidenced in Table 4

The results about the PPC imply that the shorter the days or the average collection period, the greater the return on assets, this is because in the shortest time available cash is obtained for the company, and that they can be used to invest, comply with obligations or debts

The average for PPC was 50.37 days. This implied that, during the accounts receivable period, the companies in the sample waited an average of 50 days to collect cash from credit sales or that approximately every 50 days they receive payments from their customers. This implies that companies in the industrial sector improve their profitability when the time in days to make their payments to customers is less.

\subsection{Direct Relationship Between the Average Period of Accounts Payable and Profitability}

The results indicate that there is a positive correlation between the average payment period (PPP) and the profitability of assets (ROA), with a 0.000249050 , which is shown in Table 4.

The average PPP was 53.71 days, this means that payments to suppliers are made on average every 53 days. This implies that companies in the industrial sector should not take into account the analysis of accounts payable to improve their operating margin.

\section{Conclusions}

Working Capital is an essential part of a company's short-term financing, which is why it must be managed cautiously to ensure timely obtaining and optimal use of resources. The need is evident that every company has an appropriate level of it, at the beginning of its operations. In this way, you can meet the obligations that arise in the short term, otherwise, you must necessarily use external financing.

A company manages to be more efficient, effective and competitive to the extent that it improves the management of working capital, which is achieved if it achieves an effective management of financial resources, an equitable policy of credit to customers, an adequate inventory management and an appropriate management of the leverage of suppliers and short term.

The existence of working capital is closely linked to the liquidity condition of the company. In that sense, an adequate management of working capital avoids the imbalances that cause illiquidity situations and that force the suspension of payments or even jeopardize the survival of the company due to lack of credit. The survival of the company, understood as its ability to cover its short-term obligations, or the probability of being declared technically insolvent, depends on proper management of working capital.

Finally, not all companies have the same needs or rates of generating working capital. This will depend on the type of business or activity carried out. Thus, a utility company will quickly convert investments into inventories and accounts receivable into cash. But an industrial company will have relatively slower rotations, so it will need a larger amount of working capital.

\section{References}

Albisetti, R. (2018). Finanza empresarial: Estrategia, mercados y negocios estructurados. Editorial Pontificia Universidad Javeriana. https://doi.org/10.2307/j.ctv86dg9v

Azapa, N. (2017). Administración financiera del capital de trabajo como herramienta para lograr competitividad y sostenibilidad en las microempresas del sector comercial del mercado metropolitano J.L.B Y R. - "Andrés Avelino Cáceres año 2015" (tesis para optar el título profesional de: Contador Público). Universidad Nacional de San Agustín de Arequipa.

Brealey, R., Marcus, A., \& Myers, S. (2015). Principios de Finanzas Corporativas (11th ed.). México, D. F.: 
McGraw-Hill/Interamericana editores.

Cabrera, R. C. (n.d.). Bases para Contabilidad LEAN. Retrieved from https://books.google.com.pe/books?id=LfezJ7luS5wC\&pg=PA16\&dq=periodo+promedio+de+cobro\&hl=es\&sa $=X \& v e d=0$ ahUKEwiRtb2g-LrmAhUXH7kGHXJRC8AQ6AEIRjAE\#v=onepage\&q=periodo $\% 20$ promedio $\% 20$ $\mathrm{de} \% 20$ cobro\&f $=$ false

Castañeda, E. (2016). La administración de capital de trabajo y su influencia en la gestión empresarial de la empresa constructora Génesis SAC. del distrito de Trujillo, 2014 (tesis para optar el grado de contador público). Universidad Nacional de Trujillo.

Cisne, M., Rojas, D., Cueva, D., \& Armas, R. (2018). The Management of Working Capital and its effect on the Profitability of the Construction Companies of Ecuador. X-Pedientes Económicos, 2(3), 28-45.

Dalci, I., Tanova, C., Ozyapici H., \& Bein, M. (2019).The Moderating Impact of Firms size on the Relationship Between Working Capital Management and Profitability. Prague Economic Papers, (28), 296-312. https://doi.org/10.18267/j.pep.681

Deloof, M. (2003) Does working capital maganement affects profitability of Belgian firms. Journal of Bussines Finance and Accounting, 573-587. https://doi.org/10.1111/1468-5957.00008

Eljelly, A. (2004). Liquidity - profitability tradeoff: An empirical investigatin in an emerging market. International Journal of Commerce and Management, 48-61. https://doi.org/10.1108/10569210480000179

Espinoza, D. (2005). Procedimiento para el análisis del capital de trabajo (tesis para obtener el título de master en ciencias económicas). Matanzas, Cuba.

Fernandez, Á. (2004). Investigación y técnicas de Mercado. Madrid, España: Anormi S.L.

Gitman, L., \& Zutter, C. (2016). Principios de Administración Financiera. Mexico: Pearson Educación.

Jaramillo, S. (2016). Relación entre la gestión del capital de trabajo y la rentabilidad en la industria de distribución de químicos en Colombia. Revista Finanzas y Política Económica, 8(2), 327-347. http://doi.org/10.14718/revfinanzpolitecon.2016.8.2.6

Lindelwa, P., \& Zimasa, N. (2019). Working Capital Management and Financial Performance: Evidence from Listed Food and Beverage Companies in South Africa. Academy of Accounting and Financial Studies Journal, 23(2), 1-10.

Linh, N. T. P., \& Mohanlingam, S. (2018). The effects of cash conversion cycle on profitability: an insight into the agriculture and food industries in Thailand. AJBA, 11(1), 97-119. https://doi.org/10.22452/ajba.vol11no1.4

Malaret, M. (2018). Economía Peruana Destaca, pero... La Cámara. Retrieved from https://www.camaralima.org.pe/repositorioaps/0/0/par/edicion856/edicion\%20856\%20ok.pdf

Nobanee, H. (2018). Efficiency of Working Capital Management and Profitability of UAE Construction Companies: Size and Crisis Effects. https://doi.org/10.2139/ssrn.2971477

Núnez, L. (2016). Finanzas 1 Contabilidad. Planeación y Administración Financiera. Mexico, D.F.: Instituto Mexicano de Contadores Públicos.

Rodríguez, F. (2017). Finanzas 2 Finanzas Corporativas: una propuesta metodológica. Mexico: Instituto Mexicano de Contadores Públicos, A. C.

Sarwat, S., Iqbal, D., Durrani, B., Shaikh, K., \& Liaquat, F. (2017). Impact of Working Capital Management on the Profitability of firms: Case of Pakistan's Cement Sector. Journal of Advanced Management Science, 5(3), 238-244. https://doi.org/10.18178/joams.5.3.238-244

SNI 120 años Industria Peruana. (2016). Sociedad Nacional de Industrias. Retrieved from https://www.sni.org.pe/wp-content/uploads/2018/05/Industria_Peruana_914.pdf

Tanaka, G. (2001). Análisis de Estados Financieros para la toma de decisiones. Lima. Perú: Pontificia Universidad Católica del Perú.

Van Horne, J., \& Wachowicz, J. (2010). Fundamentos de Administración Financiera (13th ed.). México, D. F.: Pearson Educación. 